\title{
A study on relationship between earning conservatism with investment elasticity on Iranian firms
}

\author{
Hassan Ghordati and Mohammad Golestani Rad*
}

Department of Management and Accounting, Kashan Branch, Islamic Azad University, Kashan, Iran

\begin{tabular}{|c|c|}
\hline C H R O N I C L E & A B S T R A T \\
\hline $\begin{array}{l}\text { Article history: } \\
\text { Received December 28, } 2013 \\
\text { Received in revised format April } \\
152014 \\
\text { Accepted April } 182014 \\
\text { Available online } \\
\text { April } 232014\end{array}$ & $\begin{array}{l}\text { This paper presents an empirical investigation to see whether or not there is any relationship } \\
\text { between profit conservatism and investment sensitivity and efficiency of investments in listed } \\
\text { companies of Tehran Stock Exchange (TSE). Using regression analysis, the study investigates } \\
\text { whether there is any relationship between conservatism and sensitivity of investments, between } \\
\text { profit conservatism and efficiency of company's investments and between conservatism ability } \\
\text { to create profit and cash in accepted TSE firms. The study chooses a sample of } 102 \text { firms from }\end{array}$ \\
\hline $\begin{array}{l}\text { Keywords: } \\
\text { Profit conservatism }\end{array}$ & $\begin{array}{l}\text { TSE market over the period } 2005-2011 \text { and the results confirmed that there were positive and } \\
\text { meaningful relationship between all variables of the survey }(\alpha=5 \%) \text {. }\end{array}$ \\
\hline
\end{tabular}

C 2014 Growing Science Ltd. All rights reserved.

\section{Introduction}

Stock market investors always need to do extensive studies when buying and selling common stock and consider many factors for investing because most of its assets are converted into shares. Although, there are different accepted brokerage firms and various criteria for selecting firms for investment, it is essential that investors use various criteria to predict the effect of corporate status to become familiar with, in order to make the right decision (Asqarizade, 2011). Investment requires investment process and investors' wealth management. This wealth includes sum of current income and the present value of future income. Corporate and companies, including the production and commercialization need financial resources for expanding their activities. They published documents, which represent certain claim to shareholders to reach related resources. Securities maintain value and can be purchased or sold in financial markets. Values of these securities are determined in market and securities and issuer credit institution play essential role in determining their value; though the value of these securities may be impacted by economic and political factors.

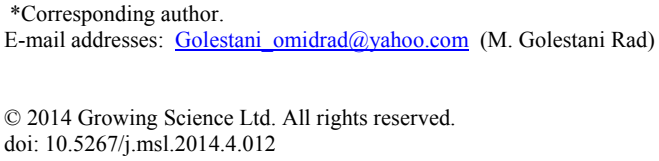


The important feature of these securities is on the capability for cash conversion. Evaluating the relationship between investment and internal resources is called "cash flow- investment conservatism". Some believe the importance of this relationship is financial constraints to which firms are encountered with. Evaluating impact of financial constraints and investment-cash-flow sensitivity factors of financial constraints has been the subject of many discussions in recent years since it is expected, firms with financial limitations will have more cost differential between domestic and foreign investors. As a result, investors should depend on internal cash flow.

Arsalan et al. (2013) investigated cash flows of Turkish firms before and after a period of financial crisis. Their findings indicated that during the financial crisis, the sensitivity of investment to cash flow increased, considerably. Also, the cash reserves was accepted criterion for determining a company's financial constraints, and firms with low cash reserves had higher cash flow- investment sensitivity. Hassani (2013) reported a relationship between cash investment sensitivity and conservatism in firms listed in Tehran Stock Exchange for the period 2004 -2010. The results showed that firms with a higher degree of reporting conservatism, could lower investment cash flow sensitivity. The results indicated that a firm with a higher degree of reporting conservatism had lower investment cash flow sensitivity.

Hosseinpoor (2013) studied listed companies in Tehran Stock Exchange to define the relationship between size, value added, and the percentage of the dividend history of the company and "cash flow sensitivity of investment". He participated in studying of 87 companies over the period 2000-2004 and reported a positive relationship between the size, value added and dividend share but there was no relationship between the history of the company and the sensitivity of investment - cash flow. Moin et al. (2013) examined the relationship between information asymmetry and the sensitivity of investment to cash flow in Tehran Stock Exchange over the period 2004-2008 by investigating 74 companies. They showed that the sensitivity of the information asymmetry and investment cash flows had significant positive relationship.

Nahandi et al. (2013) studied the relationship between audit quality and investment efficiency. A sample of 100 firms was selected over the period 2006-2011 and compound data method was applied for testing research hypothesis. The results indicated a significant positive relationship between audit quality and investment efficiency. Lenard and $\mathrm{Yu}$ (2012) investigated the relationship between audit quality and investment decisions among Chinese companies audited by the four important audit firms. The results showed that there was positive and significant relationship between audit quality and investment efficiency. They also did research about relationship between audit quality and investment decisions between Chinese companies audited by the four important audit companies. Their results show that ratio of over investment for companies that have more tenure period are low. Rather for companies that have less tenure period, over investment is about 70\%. Assadi (2011) investigated on effect of over investment on investors' reaction comparing with conserved cash related to 564 cases. He founded that there was an inverse relationship between over investment and final value. He showed that final value of cash was less than companies without over investment.

Bani Mahd et al. (2011) investigated the association between accounting conservatism and corporate governance in 71 companies in Tehran Stock Exchange during 2004 until 2009. They showed that limited sample size prevents significant model of Ball and Shiva Kumar. Besides, there was no relationship between conservatism and internal audit in Tehran Stock Exchange. Kashani-Poor and Naqi Nezhad (2009) reviewed the financial constraints and the investment sensitivity of cash flow on 96 companies listed in Tehran Stock Exchange over the period of 2002-2008. The results showed that firms with financial constraints had higher investment sensitivity to cash flow, and have bold emphasis on internal cash flows when deciding on investment.

In other study, researchers examined the problems resulting from over investment and less investment. They showed the potential conflict between management, loans property and lenders the 
capital structure of corporate governance and investment policies would influence on increasing inefficient decisions and bad investment. In addition, managers' wrong decision in choosing bad projects or high-risk investments, leading to less-than or greater, and the interests of owners and lenders to make problems. (Assadi, 2010). Huakimyan (2009) worked on the firm's investment policy in terms of increasing and decreasing cash flows. They studied on a sample consisted of 7176 firms accepted on New York Stock Exchange over the period 2000-1985. By analyzing time series, they found that there was a positive correlation between investment and cash flow. Kashani Poor and Naqi Nezhad (2009) investigated on the effect of financial constraints on the cash flow sensitivity and compared the sensitivity of investment - cash flow and sensitivity of cash flow as financial constraint measure. They used a sample of 78 companies during 2001-2006. By significance test of efficient cash reservoir, they concluded that investment cash flow sensitivity was better measure for defining financial constraints. However, they did not use optimized cash reservoir for classifying companies. Bani Mah and Baqebani (2009) did research on effect of accounting conservatism, government ownership, firm size and the ratio of leverage on firms' losses. It covers the effect of accounting conservatism, government ownership, firm size and leverage ratio of company losses in 48 loss full companies in Tehran Stock Exchange for the period of 7-years 2001 to 2007. The conservatism measure of this study was measured in terms of accruals. The results showed that accounting conservatism had a direct relationship with corporation loss. This theory has been accepted in theory. Moreover, the results emphasizes on inverse relationship between the ratio of losses and leverage ratio.

Aqaee et al. (2009) examined the factors influencing the maintenance of cash reservoir in accepted companies listed in Tehran Stock Exchange. They showed that receivable, net capital flow, commodities and short-term debt were the main factors and had a negative impact on maintaining cash reservoir. On the other hand, growth opportunities, company dividends, volatility of cash flows and net income, respectively, were the main factors and had a positive impact on cash keeping. Biddle et al. (2009) examined the relationship between quality and efficiency of financial accounting, investment and reported that the cash flow sensitivity was a better measure for identifying financial constraints. Ferreira and Villa (2004) did a research on the effect of the cash balance on investment opportunities and free cash flow to assess Europe's monetary union firms by data panel method. They found that investment opportunities and cash flows have positive impact on cash, and assets cash ability, financial leverage; firm size and bank debt have negative impact.

\section{The proposed study}

Main hypothesis: There is a relationship between profit conservatism and investment sensitivity, efficiency of investments in listed companies of Tehran Stock Exchange.

\section{Sub-hypotheses:}

1. There is a relationship between conservatism and sensitivity of investments in listed companies of Tehran Stock Exchange;

2. There is a relationship between profit conservatism and efficiency of company's investments in listed companies of Tehran Stock Exchange;

3. There is a relationship between conservatism ability to create profit and cash in accepted companies of Tehran Stock Exchange.

The population was selected from companies listed in Tehran Stock Exchange, which are not investment or financial intermediation type. Using Morgan and random class, a sample of 102 companies was selected. Performance of the company was based on applied data from 2005 to 2011 .

Depending on related cases, the study uses descriptive statistics methods such as mean and standard deviation. Kolmogorov-Smirnov Test (KS) is performed to verify whether the data are normally 
distributed or not. We also use combined linear regression method to analyze variables relationship and finally, t-statistic and F-value are used for generalizing parameters and evaluation relationships.

Relationship between variables is calculated based on compound linear regression as follows,

$\mathrm{CFSI}_{i t}=\beta_{0}+\beta_{1} \mathrm{CONSV}_{i t}+\beta_{2} \mathrm{CONTROLS}_{i t}+\varepsilon_{i t}$,

where $C F S I_{i t}$ represents sensitivity and it is calculated as follows,

$$
C F S I_{i t}=\sum_{t=1}^{n}\left(I_{i t} \times \frac{C F_{i t}}{\sum_{t=1}^{n} C F_{i t}}\right)-\frac{1}{n} \sum_{t=1}^{n} I_{i t} .
$$

Here, $C F_{i t}$ represents investment profit, $I_{i t}$ asset cost, $C O N S V_{i t}$ states profit investment. In our study, conservatism is calculated as follows,

$$
R E V E N U E_{i t}=\beta_{0}+\beta_{1} E X P_{t-1}+\beta_{2} E X P_{t}+\beta_{3} E X P_{t+1}+\varepsilon_{i t},
$$

where REVENUE $E_{i t}$ states revenue of company $i$ at time $t, E X P$ states profit before decreasing unpredictable items, CONTROLS $S_{\text {it }}$ states control variable, which is equal to logarithm of total assets. For studying the relationship between profit conservatism and investment profit, the study uses the following model,

$$
N R O I_{i t}=\alpha+\beta_{0} F C F_{i t}+\beta_{1} \operatorname{CONSV}_{i t}+\beta_{2} F C F_{i t} * \operatorname{CONSV}_{t-1}+\beta_{3} \operatorname{CONTROLS}_{i t}+\varepsilon_{i t},
$$

where $N R O L_{i t}$ represents investment output and $F C F_{i t}$ denotes free cash flow. For studying the relationship between profit conservatism and ability to create cash we can use the following regression model,

CFLOW $_{i t}=\beta_{0}+\beta_{1} \Delta$ CASH $_{i t}+\beta_{2}$ CASH $_{i t}+\beta_{3} \operatorname{CONSV}_{i t}+\beta_{4} \Delta$ CASH $_{i t} * \operatorname{CONSV}_{i t}+\beta_{5} \operatorname{CONTROLS}_{i t}+\varepsilon_{i t}$,

where $\triangle C A S H_{i t}$ represents cash change, CONTROLS $S_{i t}$ is a control variable, which is equal to logarithm of total assets and finally, $C F L O W_{i t}$ represents the ability of generating cash.

\section{The results}

In this section, first, we describe data based on statistical indexes, then after studying default compound linear regression, we define relationship between variables. Statistical variables are described using by statistical parameters including mean, standard deviation and Table 1 shows related results. Table 1 shows the characteristics of the study variables. First row in this table represents that number of all data for all studied variables is 618 number - year. The second row shows collected variables separately, for example, change average of cash is 10967.02. Sixth row shows variance and the dispersion around the average variable, which change variance in cash is $1.439 \mathrm{E}+10$. Seventh and eight rows are skewness and data elongation comparing normal bell shaped curve. The highest skewness to the right side is 18,890 . The ninth and tenth lines show the highest and lowest changes as change range which minimum data for cash change variable is 1031858 , and maximum data is 1242076. Evaluation of normal distributed variables as the default composite linear regression was accomplished based on Kolmogorov test. Table 2 and Table 3 present the summary of the results of the regular and converted data. 
Table 1

The summary of some basic statistics

\begin{tabular}{|c|c|c|c|c|c|}
\hline Variable & CONTRO & NROI & CFSI & fcf & $\mathrm{CASH}$ \\
\hline Data quantity & 612 & 612 & 612 & 612 & 612 \\
\hline Mean & 5.847657 & 0.595784 & -2682.2316 & 281194.39 & 86136.31 \\
\hline Median & 5.790686 & 0.071816 & -179.29162 & 49580.5 & 14969 \\
\hline Mode & $4.8065^{\mathrm{a}}$ & 0.0333 & 0 & $0^{\mathrm{a}}$ & $572^{\mathrm{a}}$ \\
\hline Standard deviation & 0.5944066 & 4.5403287 & $1.09 \mathrm{E}+06$ & $1.05 \mathrm{E}+06$ & 305090.87 \\
\hline variance & 0.353 & 20.615 & $1.19 \mathrm{E}+12$ & $1.11 \mathrm{E}+12$ & $9.31 \mathrm{E}+10$ \\
\hline Skewness & 0.744 & 18.89 & 4.93 & 6.247 & 6.696 \\
\hline elongation & 0.786 & 409.79 & 110.099 & 45.473 & 49.73 \\
\hline Minimum data & 4.6597 & 0 & $-8.56 \mathrm{E}+06$ & -2413332 & 0 \\
\hline Maximum data & 7.9285 & 102.1503 & $1.64 \mathrm{E}+07$ & 10513630 & 3032832 \\
\hline Total & 3613.8522 & 368.1943 & $-1.66 \mathrm{E}+06$ & 173778131 & 53232241 \\
\hline Variable & DELTA.C & CFLOW & DELTA.CASH.CONSV & FCF.CONSV & CONSV \\
\hline Data quantity & 612 & 612 & 612 & 612 & 612 \\
\hline Mean & 10967.02 & 5.066111 & $2.00 \mathrm{E}+11$ & $4.39 \mathrm{E}+12$ & $1.53 \mathrm{E}+06$ \\
\hline Median & 759 & 1.303848 & $9.62 \mathrm{E}+07$ & $1.07 \mathrm{E}+10$ & 316174.13 \\
\hline mode & 0 & 0 & 0 & 0 & $114113.45^{\mathrm{a}}$ \\
\hline Standard deviation & 119973.58 & 19.989133 & $3.45 \mathrm{E}+12$ & $3.26 \mathrm{E}+13$ & $4.60 \mathrm{E}+06$ \\
\hline variance & $1.44 \mathrm{E}+10$ & 399.565 & $1.19 \mathrm{E}+25$ & $1.07 \mathrm{E}+27$ & $2.12 \mathrm{E}+13$ \\
\hline Skewness & 2.489 & 8.361 & 2.197 & 10.487 & 6.422 \\
\hline elongation & 45.652 & 81.046 & 105.571 & 121.999 & 48.895 \\
\hline Minimum data & -1031858 & $-3.01 E+01$ & $-4.58 \mathrm{E}+13$ & $-9.69 E+12$ & $-3.09 E+06$ \\
\hline Maximum data & 1242076 & 242.4017 & $3.41 \mathrm{E}+13$ & $4.40 \mathrm{E}+14$ & $4.44 \mathrm{E}+07$ \\
\hline Total & 6777621 & 3130.8565 & $1.24 \mathrm{E}+14$ & $2.71 \mathrm{E}+15$ & $9.45 \mathrm{E}+08$ \\
\hline
\end{tabular}

\section{Table 2}

The summary of Kolmogorov-Smirnove test

\begin{tabular}{|c|c|c|c|c|c|c|c|c|c|}
\hline Variable & NROI & fcf & CONSV & FCF.CONSV & CONTROLS & CFLOW & DELTA.CASH & CASH & CFSI \\
\hline Data quantity & 612 & 612 & 612 & 612 & 612 & 612 & 612 & 612 & 612 \\
\hline Mean & 0.601575 & 281148.35 & $1.52 \mathrm{E}+06$ & $4.43 \mathrm{E}+12$ & 5.844691 & 3.633815 & 11033.49 & 86765.34 & -2548.315365 \\
\hline Std. dev. & 4.5621878 & 1058810.9 & $4.62 \mathrm{E}+06$ & $3.28 \mathrm{E}+13$ & 0.5964409 & 11.023912 & 120536.06 & 306513.97 & $1.10 \mathrm{E}+06$ \\
\hline The max. abs. dev. & 0.448 & 0.353 & 0.336 & 0.464 & 0.073 & 0.315 & 0.314 & 0.389 & 0.384 \\
\hline $\begin{array}{l}\text { The maximum } \\
\text { positive deviation }\end{array}$ & 0.422 & 0.353 & 0.336 & 0.464 & 0.073 & 0.285 & 0.314 & 0.36 & 0.384 \\
\hline $\begin{array}{l}\text { The maximum } \\
\text { negative deviation }\end{array}$ & -0.448 & -0.339 & -0.334 & -0.427 & -0.035 & -0.315 & -0.307 & -0.389 & -0.369 \\
\hline Median quantity $\mathrm{Z}$ & 11.072 & 8.742 & 8.304 & 11.47 & 1.816 & 7.794 & 7.778 & 9.612 & 9.491 \\
\hline Sig. & 0.000 & 0.000 & 0.000 & 0.000 & 0.003 & 0.000 & 0.000 & 0.000 & 0.000 \\
\hline
\end{tabular}

\section{Table 3}

The summary of Kolmogorov-Smirnove test for the converted data

\begin{tabular}{|c|c|c|c|c|c|c|c|c|c|}
\hline Abbreviation & lnNRO & LNFCF & LNCONSV & LNFCF.CONSV & LNCONTROLS & lnCFLOW & LNDELTA.CASH & LNCASH & $\operatorname{lnCFSI}$ \\
\hline Data quantity & 612 & 612 & 612 & 612 & 612 & 612 & 612 & 612 & 612 \\
\hline Mean & -6.3348 & 21.9571 & 25.5728 & 47.5132 & 3.521 & 0.4838 & 17.7537 & 19.5044 & 18.117 \\
\hline Std. dev. & 5.26867 & 3.52586 & 3.42236 & 6.4246 & 0.19912 & 3.0918 & 3.7087 & 3.20624 & 5.83918 \\
\hline The max. abs. dev. & 0.113 & 0.034 & 0.038 & 0.04 & 0.053 & 0.046 & 0.037 & 0.056 & 0.042 \\
\hline $\begin{array}{l}\text { The maximum } \\
\text { positive deviation }\end{array}$ & 0.073 & 0.034 & 0.036 & 0.04 & 0.053 & 0.024 & 0.032 & 0.056 & 0.019 \\
\hline $\begin{array}{l}\text { The maximum } \\
\text { negative deviation }\end{array}$ & -0.113 & -0.022 & -0.038 & -0.03 & -0.024 & -0.046 & -0.037 & -0.033 & -0.042 \\
\hline Median quantity $\mathrm{Z}$ & 2.79 & 0.845 & 0.948 & 0.987 & 1.307 & 1.145 & 0.907 & 1.385 & 1.029 \\
\hline Sig. & 0.125 & 0.473 & 0.33 & 0.285 & 0.066 & 0.145 & 0.383 & 0.053 & 0.24 \\
\hline
\end{tabular}

Since the significance level ( $\mathrm{Sig}$ ) in the variables is bigger than $0.05, \mathrm{H}_{0}$ is accepted and the alternative hypothesis, $\mathrm{H}_{1}$, is rejected. In other words, data was distributed normally. In order to 
examine the stability of the data and find out whether the data are stationary or not we have performed augmented Dickey-Fuller (ADF) and Table 4 shows the results of our findings. Based on these results, P-Value of all independent variables as well as dependent variable and the adjustment in unit root test were less than 0.05 , which indicates that variables were stationary. To select the panel data methods and data fusion, the Limmer F test is used (See Table 5).

Table 4

The summary of ADF test

\begin{tabular}{llrr}
\hline Variable type & Abbreviation & Median & Sig. \\
\hline \multirow{3}{*}{ Dependent variable } & NROI & 206.584 & 0.000 \\
& CFSI & 92.1305 & 0.000 \\
\hline Independent variable & CFLOW & 188.393 & 0.000 \\
\hline \multirow{4}{*}{ Moderator variable } & CONSV & 125.4609 & 0.000 \\
& CONTROLS & 165.461 & 0.000 \\
& Fcf & 99.9087 & 0.000 \\
& CASH & 398.53 & 0.000 \\
& DELTA.CASH & 192.969 & 0.000 \\
& DELTA.CASH.CONSV & 98.8937 & 0.000 \\
& FCF.CONSV & 126.666 & 0.000 \\
\hline
\end{tabular}

Table 5

The summary of Limmer test

\begin{tabular}{lllll}
\hline Zero Hypothesis $\left(\mathrm{H}_{0}\right)$ & Models & F Limmer Intermediate & Possibility & Results \\
\hline Compound data & Model $(1)$ & 21.412 & 0.000 & $\mathrm{H}_{0}$ is rejected \\
(Intercept of all sections are the same) & Model(2) & 25.541 & 0.000 & $\mathrm{H}_{0}$ is rejected \\
& Model(3) & 28.461 & 0.000 & $\mathrm{H}_{0}$ is rejected \\
\hline
\end{tabular}

As we can see, the probability of the F Limmer test for all models is smaller than 0.05 . Therefore, there are personal or group effects and we should use panel data methods for the estimation of data. In addition, to find out whether we should choose fixed effect or random effect or to detect differences in fixed or random cross-sectional units, the Hausman test was used. Table 6 shows related results.

\section{Table 6}

The summary of Hausman test results

\begin{tabular}{ccccc}
\hline Zero Hypothesis $\left(\mathrm{H}_{0}\right)$ & Models & Intermediate & Possibility & Results \\
\hline Random effect models & Model $(1)$ & 4.8549 & 0.4125 & $\mathrm{H}_{0}$ is accepted \\
& Model(2) & 4.1024 & 0.4056 & $\mathrm{H}_{0}$ is accepted \\
& Model(3) & 3.3054 & 0.4982 & $\mathrm{H}_{0}$ is accepted \\
\hline
\end{tabular}

Based on these results and considering research models, the probability of Hausman test for determining the fixed effects versus random-effects model is more than 0.05 . Therefore, there is no relationship between the regression error estimated by the independent variables and independent variables. The most appropriate way to determine the relationship between variables is random effects model. Based on the evaluation results of defaults, compound linear regression is used to determine relationships between variables. Investors relationship between sensitivity and conservatism: A complex linear regression was used to evaluate this relationship Table 7 shows related results. The results of estimation show that the t-test probability was less than 0.05 for independent and moderating variables. Therefore, there is a significance relationship between investment return and conservatism. 
Table 7

Estimates of the sensitivity of the relationship between investment and conservatism

\begin{tabular}{lllll}
\hline Variables & Estimated coefficient & Standard deviation & T test median & T Test possibility \\
\hline CONSV & 0.180616 & 0.031792 & 5.681165 & 0.0000 \\
CONTROLS & -0.083722 & 0.010059 & -8.323387 & 0.0000 \\
C & -3.378663 & 0.409511 & -8.250482 & 0.0000 \\
The coefficient of determination & 0.567478 & Akaike criterion & -3.884271 \\
Adjusted coefficient of determination & 0.502417 & Schwartz test & -3.836172 \\
F Limmer Median & 37.88391 & Quick Hanan criteria & -3.865260 \\
F Limmer Possibility & 0.000 & Durbin-Watson stat & 2.374661 \\
\hline
\end{tabular}

The coefficient of determination indicates that $56.74 \%$ of the variation is presented by the estimated equation. Since, Durbin-Watson is between 1.5 and 2.5 and there is no autocorrelation in the model. By parameters placement, variables relationships are defined as follows,

CFSI $_{i t}=-3.378663+0.180616 * \operatorname{CONSV}_{i t}-0.083722 * \operatorname{CONTROLS}_{i t}$

In order to study the relationship between return on investment and conservatism we have used compound linear regression to determine this relationship. Table 8 shows related results:

\section{Table 8}

Evaluation of relationship between investment returns and conservatism

\begin{tabular}{lcccc}
\hline variables & Estimated coefficient & Standard deviation & T test median & T Test possibility \\
\hline FCF & 0.170599 & 0.007254 & 23.51637 & 0.0000 \\
CONSV & 0.111293 & 0.001715 & 64.88928 & 0.0000 \\
FCF.CONSV & 0.767851 & 0.008798 & 87.27111 & 0.0000 \\
CONTROLS & 0.077440 & 0.016191 & 4.783017 & 0.0000 \\
C & 0.019807 & 0.001236 & 16.02449 & 0.0000 \\
The coefficient of determination & 0.751303 & & Akaike criterion & -6.595142 \\
Adjusted coefficient of determination & 0.750833 & & Schwartz test & -6.547043 \\
F Limmer Median & 2026.760 & & Quick Hanan criteria & -6.576131 \\
F Limmer Possibility & 0.000 & Durbin-Watson stat & 1.854782 \\
\hline
\end{tabular}

Results of estimation show the t-test probability is less than $5 \%$ for independent and moderating variables. Therefore, there is a significance relationship between investment return and conservatism. The coefficient of determination indicates that $75.13 \%$ of the variation is presented by the estimated equation. Since, Durbin-Watson is between 1.5 and 2.5, there is no autocorrelation in the model. By parameters placement, variables relationships are defined as follows:

$$
\begin{gathered}
\text { NROI }_{i t}=0.019807+0.170599 * F C F_{i t}+0.111293 * \text { CONSV }_{i t}+0.767851 * F C F_{i t} \\
* \text { CONSV }_{t-1}+0.077440 * \text { CONTROLS }_{i t}
\end{gathered}
$$

In order to study the relationship between ability to make cash and conservatism, we used compound linear regression to determine this relationship. Table 9 shows the results of our survey:

\section{Table 9}

The results of investigating the relationship between ability to make cash and conservatism

\begin{tabular}{lllll}
\hline Variables & Estimated coefficient & Standard deviation & T test median & T Test possibility \\
\hline DELTA.CASH & 0.170599 & 0.007254 & 23.51637 & 0.0000 \\
CASH & 0.111293 & 0.001715 & 64.88928 & 0.0000 \\
CONSV & 0.767851 & 0.008798 & 87.27111 & 0.0000 \\
DELTA.CASH.CONSV & 0.077440 & 0.016191 & 4.783017 & 0.0000 \\
CONTROLS & -1.563316 & $4.61 \mathrm{E}-11$ & $-3.39 \mathrm{E}+10$ & 0.0000 \\
C & 0.019807 & 0.001236 & 16.02449 & 0.0000 \\
The coefficient of determination & 0.684303 & Akaike criterion & -6.595142 \\
Adjusted coefficient of determinc & 0.645833 & Schwartz test & -6.547043 \\
F Limmer Median & 1926.760 & Quick Hanan criteria & -6.576131 \\
F Limmer Possibility & 0.000000 & Durbin-Watson stat & 1.954782 \\
\hline
\end{tabular}


Results of estimation show the t-test probability is less than $5 \%$ for independent and moderating variables. Therefore, there is a significance relationship between investment return and conservatism. The coefficient of determination indicates that $56.74 \%$ of the variation is presented by the estimated equation. Since, Durbin-Watson is between 1.5 and 2.5, there is no autocorrelation in the model. By parameters placement, variables relationships are defined as follows,

$$
\begin{gathered}
\text { CFLOW }_{\mathrm{it}}=0.019807+0.170599 * \Delta \mathrm{CASH}_{\mathrm{it}}+0.111293 * \mathrm{CASH}_{\mathrm{it}}+0.767851 * \mathrm{CONSV}_{\mathrm{it}} \\
+0.077440 * \Delta \text { CASH }_{i t} * \operatorname{CONSV}_{i t}-1.563316 * \operatorname{CONTROLS}_{i t}
\end{gathered}
$$

\section{Discussion and conclusion}

According to the hypothesis test and considering significance level of 0.01 and 0.05 percent, there is a significant relationship between conservatism and investment sensitivity in listed companies of Tehran Stock Exchange. The results show that the $\mathrm{T}$ test estimated probability for independent variable of profit conservatism is less than 5\%. That means that independent variable of profit conservatism is important factor in determining the investments sensitivity of listed companies in Tehran Stock Exchange. Positive and significant relationship between conservatism independent variable in listed companies at Tehran Stock Exchange represents a direct connection between investment sensitivity. Thus, the first hypothesis is confirmed with $95 \%$ confidence. The coefficient of determination shows the explanatory power of the independent and control variable that can explain the variability rate of $56.74 \%$, which is a very strong possibility. The probability of F-median indicates that the model is statistically significant (because the probability of $\mathrm{F}$ is less than $5 \%$ ).

Hypotheses test shows that significant level of 0.01 and $0.05 \%$ indicate correlation between investment conservatism with investment returns from accepted companies in Tehran Stock Exchange. Estimated results show that T- test probability for return independent variable is less than $5 \%$. Therefore, the estimated independent coefficient of return conservatism is statistically significant. That means independent coefficient of return conservatism is important factor in defining return from company's investments in Tehran Stock Exchange. Positive and significant relationship between the independent conservatism variable represents a direct link between independent variable of return conservatism with return of investments in listed companies in Tehran Stock Exchange Market. Thus, the second hypothesis is confirmed by $95 \%$ confidence. The coefficient of determination shows the explanatory power of the independent and control variable which is able to show $75.13 \%$ dependent variable changes. The possibility of $\mathrm{F}$ median indicates the whole model is significant (since $\mathrm{F}$ possibility is less than \%5).

Hypotheses test shows that 0.01 and 0.05 significance level, there is significant relationship between return conservatism and ability to make cash in accepted companies in Tehran Stock Exchange Market. The result shows that T-test possibility for independent return conservatism variable is less than 5\%. Therefore, it is statistically significant. That means independent return conservatism variable is important factor in making cash in accepted companies of Tehran Stock Exchange Market .

Positive and significant relationship between the independent conservatism variable represents a direct link between the independent conservatism variable with the ability of making cash in accepted companies of Tehran Stock Exchange Market. Thus, the third hypothesis is confirmed with 95\% confidence. The coefficient of determination shows the explanatory power of the independent and control variable. That could explain the variability rate of $68.43 \%$, which is a highly strong possibility. The probability of F-statistic indicates that the model is statistically significant (because the probability of $\mathrm{F}$ is less than $5 \%$ ).

The results of this survey are consistent with findings of Penman and Zhang (2002), Lipsitz (2006) and LaFond and Watts (2008). 


\section{Acknowledgement}

The authors would like to thank the anonymous referees for constructive comments on earlier version of this paper.

\section{References}

Almeida, H., Campello, M., \& Weisbach, M.S. (2004). The cash flow sensitivity of cash. Journal of Finance, 59(4), 1777-1804.

Arabbsalehy, M., \& Ashrafi, M. (2011). The role of cash reservoir in determining investment sensitivity - cash flow in companies listed in Tehran Stock Exchange. Financial Accounting Research Journal, 3(9), 75-94.

Arsalan, Ö., Florackis, C., \& Ozkan, A.(2013). The role of cash holdings in reducing investment cash flow sensitivity. Emerging Markets Review, 7(4), 320-338.

Aqaee, M.A., Nezafat, A.R., Nazemi Ardakani, M., \& Javan, A. (2009). The study of effective factors on keeping cash in accepted companies of Tehran Stock Exchange Market. Journal of Financial Research, 1-2.

Asqari zade, E., \& Hajzavar, F. (2011). An analysis on post-optimality of classifying effective factors on investment decisions in Tehran Stock Exchange Market. Journal of Accounting Studies, 65.

Assadi, E. (2010). A study on effect of over investment on investors' reaction to kept cash, MA thesis of Arak University.

Bani Mahd, B., \& Baqbani, T. (2009). Effect of accounting conservatism and state ownership and leverage ratio on companies loss. Journal of Accounting Studies, 58, 53-70.

Bani Mahd, M., Moradzade Fard, B., \& Dindar Yazdi, M. (2011). A study on relationship between conservatism and company political system. Journal of Management Accounting, 8.

Biddle, G. C., Hilary, G., \& Verdi, R. S. (2009). How does financial reporting quality relate to investment efficiency?. Journal of Accounting and Economics,48(2), 112-131.

Ferreira, M. A., \& Vilela, A. S. (2004). Why do firms hold cash? Evidence from EMU countries. European Financial Management, 10(2), 295-319.

Hassani, M. (2013). An experimental study of the relationship between cash flow sensitivity of investment and accounting conservatism (or effective contracting or perspective distorted information systems?. Accounting and Auditing Studies, 20(3).

Hovakimian, A., \& Hovakimian, G. (2009). Cash flow sensitivity of investment. European Financial Management, 15(1), 47-65.

Hosein puor, Z. (2013). A study on the relationship between influencing factors and the sensitivity of investment - cash flow in companies listed in Tehran Stock Exchange market. M.A Thesis, Beheshti University.

Kashani Poor, M., \& Naqi Nezhad, B. (2009). Effect of financial constraints on cash flow sensitivity. Financial Accounting Research, 2.

Kashani Poor, M., B., Rasekhi, S., \& Rasaeian, A. (2010). Financial constraints and the sensitivity of investment to cash flow in Tehran Stock Exchange market. Advances in Accounting, 2, 3-59.

LaFond, R., \& Watts, R. L. (2008). The information role of conservatism. The Accounting Review, 83(2), 447-478.

Lenard, M. J., \& Yu, B. (2012). Do Earnings Management and Audit Quality Influence OverInvestment by Chinese Companies?. International Journal of Economics and Finance, 4(2), 2130.

Lipsitz, G. (2006). The possessive investment in whiteness: How white people profit from identity politics. Temple University Press.

Moein, M., Nayeb Zadeh, S., \& Bakhshayesh, M. (2013). Exploring the relationship between information asymmetry and the sensitivity of investment to cash flow in Tehran Stock Exchange. Journal of Islamic Azad University, Yazd. 
Nahandi, Badavar, Y., \& Taghizadeh, V. (2013). A study on relationship between audit quality and investment efficiency. Accounting Review, 20(2).

Penman, S. H., \& Zhang, X. J. (2002). Accounting conservatism, the quality of earnings, and stock returns. The Accounting Review, 77(2), 237-264.

Schoubben, F., \& Van Hulle, C. (2007). The impact of growth opportunities on the investment-cash flow sensitivity. Available at SSRN 1101685. 